Www.jmscr.igmpublication.org

Index Copernicus Value: 79.54

ISSN (e)-2347-176x ISSN (p) 2455-0450

crossrefDOI: https://dx.doi.org/10.18535/jmscr/v7i2.93

Original Research Article

\title{
Platelet to Lymphocyte Ratio, Platelet and Lymphocyte Counts in Assessing the Severity of Disease in Valvular Heart Diseases
}

\author{
Authors \\ Dr Yogita Devi ${ }^{1}$, Dr Kalaivani Selvi ${ }^{2 *}$ \\ ${ }^{1}$ Post-graduate student, ${ }^{2}$ Assistant Professor, Department of Pathology, Sri Manakula Vinayagar Medical \\ College and Hospital, Kalitheerthalkuppam, Pondicherry, 605107, India \\ *Corresponding Author \\ Dr Kalaivani Selvi \\ Email:klvnselvi@yahoo.co.in
}

\begin{abstract}
Background: Valvular heart disease (VHD) is becoming a major public health concern in developing countries. Platelet-to-lymphocyte ratio $(P L R)$ is a novel inflammatory marker used as a prognostic factor in VHD and various other diseases.

Aims and Objectives: To assess the utility of PLR, platelet and lymphocyte counts for assessing the severity of valvular heart disesase.

Materials and Methods: The study was conducted in the Department of Pathology for a period of one and half years from November 2016 to May 2018 which included 40 cases of valvular heart disease who underwent surgery in the Cardio-Thoracic and Vascular Surgery Department of a tertiary care hospital and 40 healthy subjects with normal cardiovascular status as control. ECHO was used to classify the VHD patients as mild-to-moderate and severe cases. Platelet, lymphocyte counts and PLR ratio was compared between the cases and controls using unpaired t-test. A p value <0.05 was considered statistically significant.
\end{abstract}

Observation and Results: PLR was found to be significantly higher in patients with severe VHD ( $p$ value $<0.05)$ than in controls but was not found to be significantly higher in mild-to-moderate cases. Platelet counts and lymphocyte counts were found to be statistically insignificant $(p>0.05)$.

Conclusion: High PLR is found to be associated with severe valvular heart disease and can be used as a marker for assessing severity of valvular disease.

Keywords: Valvular heart diaeases, platelet to lymphocyte ratio, platelet counts, lymphocyte counts.

\section{Introduction}

Valvular heart disease (VHD) is caused by either defect or damage in any one of the four heart valves and is becoming a major public health concern in developing countries. ${ }^{1}$ They may be congenital or acquired and rheumatic or non- rheumatic in origin. Valvular heart diseases are basically of two types: valvular stenosis and insufficiency. ${ }^{2}$ Risk factors for VHD are age, gender, hypertension, smoking and hypercholesterolemia. ${ }^{3}$ 
Rheumatic heart disease (RHD) accounts for most cases of VHD in the developing nations. ${ }^{4}$ In a study conducted by Indian Council of Medical Research (ICMR) in 10 different centers in India, the prevalence of RHD was found to range from 0.1 to $1.2 / 1000$ school children. ${ }^{5}$

Inflammation plays an important role in fibrosis formation and leaflet thickening, which results in severe stenosis of valve. During sustained inflammation, lymphocyte counts decrease as a result of increased lymphocyte apoptosis. Platelets play a role in transportation of leukocytes to the sites of inflammation and vascular injury and also in mobilizing anti-inflammatory, proinflammatory and angiogenic factors into peripheral circulation. ${ }^{6}$ The resulting inflammatory conditions lead to increased proliferation in megakaryocytic series and relative thrombocytosis.

Treatments are available to decrease inflammation and reduce the acceleration of degenerative valve stenosis. It is, therefore crucial to use a biomarker to foresee the progression of valve stenosis.

Platelet-to-lymphocyte ratio (PLR) is a novel inflammatory marker used as a prognostic factor in various diseases like coronary artery disease. ${ }^{7}$ It combines the predictive risk of platelet counts as well as lymphocyte counts into one entity which may be better than either counts alone for monitoring the inflammatory burden and also for assessing progression of valvular disease.

\section{Aims and Objective}

The aim of this study was to assess the utility of PLR, platelet and lymphocyte counts for assessing the severity of valvular heart diseases.

\section{Material and Methods}

The study was conducted in the Department of Pathology for a period of one and half years from November 2016 to May 2018 which included 40 cases of valvular heart disease who underwent surgery in the Cardio-Thoracic and Vascular Surgery Department of a tertiary care hospital and 40 healthy subjects with normal cardiovascular status as control. ECHO was used to classify the VHD patients as mild-to-moderate and severe cases.

Hematological parameters such as lymphocyte count and platelet count were measured using autoanalyzer ABX Pentra DF 120L. PLR was defined as the absolute platelet count divided by the absolute lymphocyte count. Platelet, lymphocyte counts and PLR ratio was compared between the mild-to-moderate cases and severe cases with control using unpaired t-test. Data was analyzed using EpiData version 2.2.2.186 using unpaired t-test and $\mathrm{p}$ value $<0.05$ was considered statistically significant.

\section{Results}

The age of the study participants ranged from 1765 years in patients with VHD and 16-80 years in the control group. The patients were predominantly females in the group with VHD, whereas males were predominant in the control group (Table 1).

Table 1: Demographic characteristics of the study population

\begin{tabular}{|l|c|c|}
\hline & $\begin{array}{c}\text { PATIENTS WITH VHD (N=40) } \\
\text { MEAN } \pm \text { SD }\end{array}$ & $\begin{array}{c}\text { CONTROL (N=40) } \\
\text { MEAN } \pm \text { SD }\end{array}$ \\
\hline $\begin{array}{l}\text { MEAN AGE } \\
\text { Years) }\end{array}$ & $39.7 \pm 13.2$ & $39.53 \pm 17.1$ \\
\hline $\begin{array}{l}\text { GENDER (\%) } \\
\text { MALE }\end{array}$ & $37.5 \%$ & $67.5 \%$ \\
\hline FEMALE & $62.5 \%$ & $32.5 \%$ \\
\hline
\end{tabular}

Based on ECHO findings, out of the 40 patients of VHD, 6 cases had mild-to-moderate disease and 34 cases had severe disease. 
Table 2: Hematological parameters in patients with severe VHD and control group

\begin{tabular}{|l|c|c|c|}
\hline & $\begin{array}{c}\text { PATIENTS WITH SEVERE } \\
\text { VHD }\end{array}$ & CONTROL & VALUE \\
\hline $\begin{array}{l}\text { Lymphocyte count } \\
\left(\text { cells/mm }{ }^{3}\right)\end{array}$ & $2201.32 \pm 785.1$ & $2421.40 \pm 746.8$ & 0.22 \\
& $\begin{array}{c}\text { Minimum- 801 } \\
\text { Maximum- 4560 }\end{array}$ & $\begin{array}{c}\text { Minimum- 1288 } \\
\text { Maximum- 4365 }\end{array}$ \\
\hline $\begin{array}{l}\text { Platelet count } \\
\left(\text { cells/mm }{ }^{3}\right)\end{array}$ & $260240 \pm 69860$ & $257650 \pm 51180$ & 0.85 \\
& Minimum- 112000 & Minimum- 166000 & \\
\hline $\begin{array}{l}\text { Platelet to lymphocyte } \\
\text { ratio }\end{array}$ & Maximum- 375000 & Maximum- 381000 & \\
& Minimum- 49 & $110.8 \pm 27.83$ & 0.043 \\
& Minimum- 68 & \\
\hline
\end{tabular}

Table 3: Hematological parameters in patients with mild-to-moderate VHD and control group

\begin{tabular}{|c|c|c|c|}
\hline & $\begin{array}{l}\text { PATIENTS WITH MILD- } \\
\text { MODERATE VHD }\end{array}$ & CONTROL & p VALUE \\
\hline $\begin{array}{l}\text { Lymphocyte counts } \\
\left(\text { cells } / \mathrm{mm}^{3}\right)\end{array}$ & $\begin{array}{l}1973.50 \pm 654.72 \\
\text { Minimum- } 1376 \\
\text { Maximum- } 3172\end{array}$ & $\begin{array}{l}2421.40 \pm 746.8 \\
\text { Minimum- } 1288 \\
\text { Maximum- } 4365\end{array}$ & 0.17 \\
\hline $\begin{array}{l}\text { Platelet count } \\
\left(\text { cells } / \mathrm{mm}^{3}\right)\end{array}$ & $\begin{array}{c}251666 \pm 51161 \\
\text { Minimum- } 206000 \\
\text { Maximum- } 341000\end{array}$ & $\begin{array}{c}257650 \pm 51180 \\
\text { Minimum- } 166000 \\
\text { Maximum- } 381000\end{array}$ & 0.79 \\
\hline $\begin{array}{l}\text { Platelet } \\
\text { lymphocyte ratio }\end{array}$ & $\begin{array}{l}136.17 \pm 36.00 \\
\text { Minimum- } 101 \\
\text { Maximum- } 205\end{array}$ & $\begin{array}{c}110.85 \pm 27.83 \\
\text { Minimum- } 68 \\
\text { Maximum- } 176\end{array}$ & 0.051 \\
\hline
\end{tabular}

The present study demonstrated that platelet to lymphocyte ratio is found to be significantly higher in patients with severe VHD than in patients with normal cardiovascular status with a $\mathrm{p}$ value of 0.043 (Table 2). However, PLR did not vary significantly between the mild-to-moderate and control group (Table 3). Platelet count and lymphocyte count were found to be statistically insignificant $(\mathrm{p}>0.05)$.

\section{Discussion}

Edem et al demonstrated that PLR was significantly higher in patients with aortic valve stenosis $(197 \pm 49)$ when compared to the control group (144 \pm 40$)$. They also found that PLR values over 188 predicted the severity of aortic stenosis with a sensitivity of $87 \%$ and a specificity of $70 \% .^{8}$

Akdag et al also found similar findings in AS patients with significantly higher PLR in severe and mild-to-moderate AS groups when compared to the control subjects $(151 \pm 31.2, \mathrm{p}<0.001$, $138 \pm 28.8$ vs. $126 \pm 26.5, \mathrm{p}=0.008$, respectively). Furthermore they also demonstrated PLR to be significantly higher in severe AS group compared to mild-to-moderate group. ${ }^{9}$
In the present study too, PLR was found to be significantly higher in patients with VHD as compared to patients with normal cardiovascular status. Platelet counts and lymphocyte counts were found to be statistically insignificant. Futher studies with larger study populations are required for validating the utility of platelet and lymphocyte counts in assessing severity of VHD.

\section{Conclusion}

Higher platelet to lymphocyte ratio is found to be associated with severe valvular disease and can be used as a marker for assessing severity of valvular disease.

\section{References}

1. Stewart BF, Siscovick D, Lind BK, Gardin JM, Gottdiener JS, Smith VE, et al. Clinical factors associated with calcific aortic valve disease. Cardiovascular Health Study. J Am Coll Cardiol [Internet]. 1997 Mar 1 [cited 2018 Sep 23];29(3):630-4. Available from: http://www.ncbi.nlm.nih.gov/pubmed/906 0903 
2. Schoen F. The Heart. In: Kumar V, Abbas A, Fausto N, editors. Robbins and Cotran pathologic basis of disease. $7^{\text {th }}$ ed. Philadelphia: Elsevier Saunders; 2008. p. 588.

3. Zeng Y, Sun R, Li X, Liu M, Chen S, Zhang P. Pathophysiology of valvular heart disease (Review). Exp Ther Med. 2016;11(4):1184-8.

4. Maganti K, Rigolin VH, Sarano ME, Bonow RO. Valvular heart disease: Diagnosis and management. Mayo Clin Proc. 2010;85(5):483-500.

5. ICMR. Jai vigyan mission mode project community control of rheumatic fever / rheumatic heart disease in India. 2010

6. Kapur R, Semple JW. Platelet functions beyond hemostasis. Mol Cell Biol Platelet Form Implic Heal Dis. 2017;(June):22137.

7. Yüksel M, Yıldız A, Oylumlu M, Akyüz A, Aydin M, Kaya $H$, et al. The association between platelet/lymphocyte ratio and coronary artery disease severity. Anadolu Kardiyol Derg. 2015;15(8):6407.

8. Edem E, Reyhanoğlu H, Küçükukur M, Kırdök AH, Kınay AO, Tekin ÜI, et al. Predictive value of platelet-to-lymphocyte ratio in severe degenerative aortic valve stenosis. J Res Med Sci. 2016;21(6):1-5.

9. Akdag S, Akyol A, Asker M, Duz R, Gumrukcuoglu HA. Platelet-toLymphocyte Ratio May Predict the Severity of Calcific Aortic Stenosis. Med Sci Monit [Internet]. 2015;21:3395-400. Available from: http://www.medscimonit.com/abstract/ind ex/idArt/894774. 